\title{
Christian Body, Christian Self: Concepts of Early Christian Personhood
}

Ed. by Clare K. Rothschild and Trevor W. Thompson with the assistance of Robert S. Kinney

[Christlicher Körper, christliches Selbst. Konzepte der frühchristlichen Persönlichkeit.]

Veröffentlicht auf Englisch.

In zahlreichen frühchristlichen Texten ist von Körper und Selbst die Rede. Der Sprachgebrauch variiert jedoch von Text zu Text erheblich. Derzeit wird zu diesem zentralen Thema in verschiedene Richtungen geforscht: Einerseits werden mit Hilfe neuer, differenzierter Methoden des Vergleichs frühchristliche Aussagen über Körper und Selbst religiösen, philosophischen, anthropologischen, rhetorischen, medizinischen und weiteren Texten der Antike gegenübergestellt und interpretiert. Andererseits treten Ausleger in einen Dialog mit moderner Philosophie, Psychologie, Politikwissenschaft und neueren Erkenntnissen in den Naturwissenschaften, insbesondere in den Neurowissenschaften. Die Beiträge in diesem Band tragen je für sich und in ihrem Zusammenspiel zu aktuellen Debatten bei. Sie bieten detaillierte Analysen, in denen jeweils die spezifische Wahrnehmung der grundlegenden und doch rätselhaften Konzepte Körper und Selbst in den verschiedenen Texten herausgearbeitet wird.

Inhaltsübersicht

\section{Introduction}

Clare K. Rothschild and Trevor W. Thompson: Status quaestionis: Christian Body, Christian Self II. Jewish Literature

Karina Martin Hogan : The Mortal Body and the Earth in Ben Sira and the Book of the Watchers - Matthew Goff: Being Fleshly or Spiritual: Anthropological Reflection and Exegesis of Genesis 1.3 in 4QInstruction and First Corinthians - Alec J. Lucas : Distinct Portraits and Parallel Development of the Knowledge of God in Romans 1:18-32 and Wisdom of Solomon 13.15 III. Pauline Literature

2011. XIV, 370 Seiten. WUNT I 284 Troels Engberg-Pedersen: A Stoic Concept of the Person in Paul? From Galatians 5:17 to Romans 7:14-25 - Stefan Krauter: Is Romans 7:7-13 about akrasia?

IV. Canonical Gospels and Acts

Martin Meiser: Anthropologie im Markusevangelium

V. Extra-canonical Gospels and Acts

Manfred Lang : The Christian and the Roman Self: The Lukan Paul and a Roman Reading - Troy W. Martin : Clarifying a

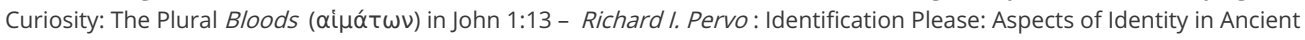
Narrative - Janet E. Spittler: The Anthropology of the Acts of Thomas - Romulus D. Stefanut: From Logos to Mythos: The Apocalypse of Paul and Plato's Phaedo in Dialogue - Robert Matthew Calhoun: The Resurrection of the Flesh in 3 Corinthians

VI. Later Witnesses

Annette Bourland Huizenga : Epitomizing Virtue: Clothing the Christian Woman's Body - David Konstan: Torture and Identity: Paganism, Christianity, and Beyond - Fritz Graf: Apollo, Possession, and Prophecy

VII. History of Interpretation

John R. Levison : Assessing the Origins of Modern Pneumatology: The Life and Legacy of Hermann Gunkel

Clare K. Rothschild Born 1964; 1986 BA University of California, Berkeley; 1992 MTS Harvard University; 2003 PhD University of Chicago; 2006 postdoctoral fellow Alexander von Humboldt Foundation at Ludwig-Maximilians-Universität München; currently Professor of Scripture, Department of Theology, Lewis University (USA) and Professor Extraordinary, Department Ancient Studies at Stellenbosch University (South Africa).

https://orcid.org/0000-0002-6572-8604

Trevor W. Thompson 1998 BA from Oklahoma Christian University; 2002 MA from Harding School of Theology; 2002 MDiv from Harding School of Theology; 2007 MA from the University of Chicago; currently PhD (Candidate), University of Chicago.

Robert S. Kinney Born 1981; 2004 BA in Early Christian Literature; 2008 MS in Journalism; 2013 ThC in Theology; 2015 PhD in New Testament; since 2005 Director of Ministries for the Charles Simeon Trust (USA).

Jetzt bestellen:

https://mohrsiebeck.com/buch/christian-body-christian-self-concepts-of-early-christian-personhood-9783161518614? no_cache=1

order@mohrsiebeck.com

Telefon: +49 (0)7071-923-17

Telefax: $+49(0) 7071-51104$ 